\title{
Cervical cancer screening in young and elderly women of the Xingu Indigenous Park: evaluation of the recommended screening age group in Brazil
}

\author{
Rastreamento do câncer de colo uterino em jovens e idosas do Parque Indígena do Xingu: \\ avaliação quanto à faixa etária preconizada no Brasil
}

\author{
Neila Maria de Góis Speck ${ }^{1}$, Juliana da Silva Pinheiro ${ }^{1}$, Erica Ribeiro Pereira ${ }^{1}$, Douglas Rodrigues ${ }^{1}$,
}

Gustavo Rubino de Azevedo Focchi ${ }^{1}$, Julisa Chamorro Lascasas Ribalta ${ }^{1}$

\begin{abstract}
Objective: To analyze the occurrence of atypia in the cytology/histology examinations of young women under the age of 25 years and of elderly women aged over 64 years, in the Xingu Indigenous Park and to evaluate, in a subjective manner, if the age range for screening established by the Ministry of Health and the Instituto Nacional de Câncer is appropriate for this population. Methods: The Xingu/ UNIFESP Project, in partnership with the Center for Gynecological Disease Prevention, develops programs to prevent cervical cancer. The exploratory, retrospective and descriptive study of cytological and histopathological examinations of young (12-24 years) and elderly (aged 64 and over) women of the Xingu Indigenous Park, between 2005 and 2011. Results: There was low occurrence of cytological atypia in the elderly female population, but there were occasional high-grade lesions in the indigenous youth. Conclusion: Interrupting screening at the limit age of 64 years, as established by the Ministry of Health and the Instituto Nacional de Câncer is justified. However, screening of young women should begin at an earlier age.
\end{abstract}

Keywords: Cervix uteri/pathology; Neoplasms; Screening; Indigenous population; Age groups

\section{RESUMO}

Objetivo: Analisar a ocorrência de atipias nos exames citológicos e histológicos de jovens e idosas indígenas, e também avaliar se a faixa etária preconizada pelo Ministério da Saúde e pelo Instituto Nacional de Câncer em rastreamento do câncer de colo uterino é adequada para essa população. Métodos: 0 Projeto Xingu/UNIFESP, em parceria com o Núcleo de Prevenção de Doenças Ginecológicas, desenvolve programas de prevenção do câncer do colo de útero. Foi realizado estudo exploratório, retrospectivo e descritivo de exames cito/histopatológicos em jovens do Parque Indígena do Xingu de 12 a 24 anos e em idosas a partir dos 64 anos, no período de 2005 a 2011. Resultados: Em idosas, houve baixa ocorrência de atipias citológicas, mas nas jovens indígenas, ocorreram casos eventuais de lesão de alto grau. Conclusão: Justifica respeitar o limite de 64 anos para a interrupção do rastreamento, como 0 estabelecido pelo Ministério da Saúde/Instituto Nacional de Câncer, mas, nas jovens, seria importante iniciar o rastreamento mais precocemente.

Descritores: Colo do útero/patologia; Neoplasias; Rastreamento; População indígena; Grupos etários

\section{INTRODUCTION}

Cervical carcinoma is the second most common malignant neoplasm that affect women in the world, with 471 thousand new cases per year and about 230 thousand deaths per year in all continents. ${ }^{(1)}$ In Brazil, the estimated number of new cases for 2014 is 15,590 , ranking third among female cancers; whereas in the Northern and Midwestern Regions of the country it ranks first. ${ }^{(2)}$

Infection by the human papillomavirus (HPV) is the most important factor for the development of this neoplasm and is sexually transmitted disease that most often affects women. Approximately 6.2 million new cases of infection occur each year only in the United States, with greater prevalence in sexually active women

\footnotetext{
1 Universidade Federal de São Paulo, São Paulo, SP, Brazil.

Corresponding author: Neila Maria de Góis Speck - Rua Borges Lagoa, 380, - Vila Clementino - Zip code: 04038-000 - São Paulo, SP, Brazil - Phone: (11) $5576-4848$ extension 2635 E-mail: neila.speck@unifesp.br

Received on: July 8, 2014 - Accepted on: Jan 7, 2015

Conflict of interest: Neila Maria de Góis Speck receives financial aid from pharmaceutical organizations to give lectures at scientific events and events-related to health area.

DOI: 10.1590/\$1679-45082015A03222
} 
aged under 25 years. A study of the natural history of the disease shows that more than $50 \%$ of young women initiating their sexual life will become positive for HPV tests after 36 months. ${ }^{(3)}$ In Brazil, massive infection was documented in adolescence, with up to $28 \%$ of abnormal cytology tests soon after the first year of coitarche.(4) Nevertheless, most adolescents with an intact immune system will have clearing of their infection within 24 months. ${ }^{(5)}$

Indigenous women also present with a high risk for HPV infection. This is due to the fact that the primary form of transmission is sexual. A few behavioral patterns are determining factors of this problem, and are considered risk factors for cancer: beginning of sexual relations at an early age, multiple sexual partners during their life time, a history of sexually transmitted diseases (STD), promiscuous sexual partners, immune deficiencies, and unfavorable socioeconomic conditions. ${ }^{(6)}$

There is worldwide consensus that cervical carcinoma can be avoided by means of early diagnosis and treatment of precursor lesions. To this end, the cervical vaginal cytological smear, known as the Papanicolaou smear, has been advocated as an efficient instrument for screening programs. ${ }^{(7)}$

Cervical cancer is preceded by a long phase of preinvasive disease, known as cervical intraepithelial neoplasia (CIN) that is classified into grades I, II, and III. If not treated, the high-grade lesions, CIN II and III, are considered precursor lesions due to their greater likelihood to progress to cancer. ${ }^{(8)}$ The cervicovaginal smear, using Papanicolaou's technique, detects these alterations. According to The 2001 Bethesda classification, the smears are characterized as negative, atypical squamous cells (ASC), atypical glandular cells (AGC), low-grade intraepithelial lesion, high-grade intraepithelial lesion, and cancer. ${ }^{(9)}$

An observational study verified that the probability of regression for CIN I is $60 \%$. For CIN II, it is $40 \%$, both for regression and for persistence. Whereas the probability of regression for CIN III is $33 \%$, and of progression to invasive carcinoma it is approximately $12 \% .{ }^{(10)}$

In adolescents, most studies demonstrated a high rate of spontaneous regression. In another study, CIN II showed remission in $40 \%$ of the cases within two years. ${ }^{(11)}$ Cancer in this population is extremely rare, and therefore, most screening programs recommend beginning the Papanicolaou smear test later, in general, at 21 to 25 years. In Brazil, the recommended age for starting cytological screening is 25 years, as per the Ministry of Health and the Instituto Nacional de Câncer (INCA). ${ }^{(12)}$ Some organizations, such as the American Association of Cancer, American Congress of Obstetricians and Gynecologists (ACOG) and the American Society for Colposcopy and Cervical Pathology (ASCCP) recommend having the first prevention test at 21 years. ${ }^{(13,14)}$

On the other hand, postmenopausal women, with no prior diagnosis of cervical disease, show a low risk of developing cervical cancer. Therefore, the MS/INCA established the interruption of screening for women aged over 64 years who present with at least two consecutive negative tests in the previous 5 years, or who present with no past history of uterine cervix disease. $^{(12)}$

As to indigenous women, some studies identified that cervical cancer is one of the primary causes of morbidity and mortality. When compared to nonindigenous women, their morbidity and mortality rates are twice as high. ${ }^{(6)}$ Few studies have shown the progression of HPV infection in this type of population, without knowing if clearing of the disease occurs in the same manner as in other ethnic groups, becoming a concern if the epidemiological cofactors might interfere in elimination of the viral infection. Another concern is the access of these women to supplementary diagnostic tests and treatment.

In 2011, the MS and INCA established new Brazilian guidelines for cervical cancer screening, setting ages for the beginning and end, and for Papanicolaou smear test specimen collection. However the guidelines do not address special populations, isolated and restricted, such as indigenous women. ${ }^{(6,15)}$ In the very recommendation of the MS/INCA, medical judgment should prevail, taking into consideration specific clinical situations.

\section{OBJECTIVE}

To analyze the occurrence of atypia in the cytology/ histology examinations of young women under the age of 25 years and of elderly women aged over 64 years, in the Xingu Indigenous Park and to evaluate, in a subjective manner, if the age range for screening established by the Ministry of Health and the Instituto Nacional de Câncer is appropriate for this population.

\section{METHODS}

A retrospective survey was done of the cytology and histology examinations on cervical and vaginal specimens of women from the Xingu Indigenous Park (PIX), in the state of Mato Grosso, during the period of 2005 to 2011. A descriptive analysis of the findings was presented, with prevalence of the alterations. For the present study, we considered samples of young 
women aged 12-24 years (1,386 samples) and of women aged over 64 years (115 samples) with current or past active sexual lives. The data were collected from the cervical cancer prevention actions developed in the PIX by the Xingu Project and the Universidade Federal Paulista (UNIFESP)/Núcleo de Prevenção de Doenças Ginecológicas (NUPREV). The samples were collected in the indigenous area by a nurse skilled for such task and sent to the Pathology Department of the Escola Paulista de Medicina (EPM). The specimens were spread on slides by the conventional technique, stained as per Papanicolaou, and classified according to the Bethesda System. All women with cytological alterations were submitted to colposcopic examinations within the indigenous area performed by a physician. Biopsies were performed only in those patients who presented with any type of atypical image in the uterine cervix, vagina and vulva. The histopathological study was processed at the Pathology Department of the EPM. The histological findings were described as per Richart classification (1967).

This study was approved by the Research Ethics Committee of UNIFESP, under number 1753/06, and by the Conselho Nacional de Ética em Pesquisa (CONEP) under number 361/2008.

\section{RESULTS}

During the years 2005, 2007, 2009, 2010, and 2011, screening actions were conducted in Xingu, with 2,903 cytology test specimens collected from sexually active women, reaching coverage of $93.4 \%$ of the female population. Cytological alterations with atypia of undetermined significance or greater (ASCUS + ) were found in $9.1 \%$ of cases. Of the total 1,386 cytology tests performed for the age group 12-24 years, representing $47.7 \%$ of the entire population studied, we obtained a mean coverage of $95.2 \%$. Of the 115 cytology tests from women aged over 64 years, representing 3.9\% of all the population screened, we obtained a mean coverage of $91 \%$. The cytology findings in all young and old population are represented on table 1 . The cytology alterations (ASCUS +) are shown on table 2, with these findings in $9.6 \%$ of the young population and $13 \%$ of the more elderly women. In the young population with cytology alterations, there was a predominance of lowgrade lesion accounting for $4.5 \%$ of all cytology tests; in the elderly, for $7 \%$. The high-grade lesions occurred in $0.5 \%$ in the young group and $2.6 \%$ in the elderly group. No case of invasive carcinoma was identified in either of the two groups investigated.
Table 1. Description of the cytology findings as per age groups 12-24 years and over 64 years

$\left.\begin{array}{lcc}\hline \text { Population } & \begin{array}{c}\mathbf{1 2 - 2 4} \text { years } \\ \mathbf{n}(\%)\end{array} & \begin{array}{c}\text { > } \\ \mathbf{6 4} \text { years } \\ \mathbf{n}(\%)\end{array} \\ \hline \text { Normal } & 1253(90.4) & 100(87) \\ \text { ASCUS } & 49(3.5) \\ \text { ASC-H } & 14(1.0) & 1(0.8) \\ \text { LGL } & 62(4.5) & 3(2.6) \\ \text { HGL } & 7(0.5) & 8(7) \\ \text { AGC } & 1(0.1) & 3(2.6)\end{array}\right\}$

Table 2. Prevalence of cytology alterations as per age group 12-24 years and over 64 years

\begin{tabular}{lcc}
\hline Alteration & $\begin{array}{c}\mathbf{1 2 - 2 4} \text { years } \\
\mathbf{n}(\%)\end{array}$ & $\begin{array}{c}>\mathbf{6 4} \text { years } \\
\mathbf{n}(\%)\end{array}$ \\
\hline ASCUS & $49(36.8)$ & $1(6.6)$ \\
ASC-H & $14(10.5)$ & $3(20)$ \\
LGL & $62(46.6)$ & $8(53.3)$ \\
HGL & $7(5.3)$ & $3(20)$ \\
AGC & $1(0.7)$ & 0 \\
\hline Total ALT & $133(100)$ & $15(100)$ \\
\hline ASCUS: atypical squamous cells of undetermined significance; ASC-H: atypical squamous cells-cannot exclude a high- \\
grade lesion; LGL: low-grade lesion; HGL: high-grade lesion; AGC: atypical glandular cells; Total ALT: total number of \\
alterations.
\end{tabular}

Table 3 shows the cytology alterations with findings of low- and high-grade lesions, in women aged under 24 years, distributing them into three age groups: $12-18$ years, 19-21 years, and 22-24 years. A high incidence was observed of low-grade lesions in women under the age of 18 years and a greater frequency of high-grade lesions in the range of 19-21 years of age.

Table 3. Distribution of cytology alterations of low- and high-grade in women aged under 24 years, as per age groups and total of alterations with proportion by age group

\begin{tabular}{|c|c|c|c|}
\hline \multirow[b]{2}{*}{ Age range (years) } & \multicolumn{2}{|c|}{ Alteration } & \multirow{2}{*}{$\begin{array}{l}\text { Total } \\
\text { n (\%) }\end{array}$} \\
\hline & $\begin{array}{c}\text { LGL } \\
\mathbf{n}(\%)\end{array}$ & $\begin{array}{c}\text { HGL } \\
\text { n (\%) }\end{array}$ & \\
\hline $12-18$ & $43(69.3)$ & $1(14.2)$ & $44(63.8)$ \\
\hline $19-21$ & $11(17.4)$ & $4(57.1)$ & $15(21.8)$ \\
\hline $22-24$ & $8(12.9)$ & $2(28.5)$ & $10(14.4)$ \\
\hline Total & $62(100)$ & $7(100)$ & $69(100)$ \\
\hline
\end{tabular}

LGL: low-grade lesion; HGL: high-grade lesion.

Whereas in the elderly, the three cases of highgrade lesions in women aged over 64 years presented with prior cytology alterations and were maintained in cytological and colposcopic surveillance during the actions of the team at Xingu. 
Table 4 presents the distribution of the colposcopyguided biopsies in women selected by their cytological alterations. In the group of young patients, low histological grade lesions prevailed in the cervix and vagina, and in the older women, there was predominance of CIN I, although in lower proportions. Whereas the highgrade neoplasms occurred in both groups, they were proportionally higher in number in the elderly group, but the number of women in this group is well inferior to that of the young group.

Table 4. Prevalence of anatomopathological alterations in women with cytology alterations for the age groups $12-24$ years and over 64 years

\begin{tabular}{lcc}
\hline AP & $\begin{array}{c}\mathbf{1 2 - 2 4} \text { years } \\
\mathbf{n}(\%)\end{array}$ & $\begin{array}{c}\mathbf{> 6 4} \text { years } \\
\mathbf{n}(\%)\end{array}$ \\
\hline CIN I & $12(40)$ & $3(50)$ \\
CIN II & $3(10)$ & $2(33.3)$ \\
CIN III & $3(10)$ & 0 \\
VAIN I & $9(30)$ & $1(16.6)$ \\
VAIN II & $1(3.3)$ & 0 \\
VIN I & $2(6.6)$ & 0 \\
\hline Total ALT & $30(100)$ & $6(100)$ \\
\hline
\end{tabular}

AP: anatomopathological; CIN: cervical intraepithelial neoplasia; VAIN: vaginal intraepithelial neoplasia; VIN: vulvar intraepithelial neoplasia; total ALT: total number of alterations.

\section{DISCUSSION}

It was noted that in the indigenous women of the Mid, Low, and East Xingu Regions, the early start of reproductive life, at approximately 15 years, sometimes occurred even earlier. Since the exercise of sexuality and conception is precocious, the reproductive period of these women, for the most part, lasts about 30 years, with high rates of fertility. ${ }^{(6)}$ Such facts place this woman at risk from the causal agent of cervical cancer, earlier than what is observed in the general population. There is no well-established cervical cancer prevention program for these indigenous women.

The World Health Organization (WHO) establishes that the performance of the cytopathological test is the best strategy for screening cervical cancer, reaching high levels of coverage (more than 80\%) for populations defined as targets and with a significant reduction of mortality by this cancer. Countries with screening rates greater than $50 \%$ show a low rate of mortality. ${ }^{(16)}$

By means of the Xingu Project/UNIFESP, screening tests have been performed in an organized manner, with annual or biannual frequency since 2005. Physicians and paramedical professionals go to the indigenous area and collect cervical and vaginal specimen for oncotic cytology testing in all sexually active women. The interval has been shorter than that recommended by most guidelines, since there is little experience with the Xingu population as to the rates of incidence and mortality by cancer, prevalence of HPV infection and HPV-related lesions.

The coverage rates have remained very high, they are greater than what is recommended by WHO, with values of more than $90 \%$. The women presenting cytological alterations with atypical squamous cells of undetermined significance or more severe (ASCUS+) were selected for a second action, including colposcopy and biopsy, if required. If the finding of the serious lesion was confirmed by histopathology, a third action was scheduled to treat this woman. In this investigation, we were able to observe that most tests were performed in the age group under 25 years. This occurred due to the fact that the young population was more predominant.

In a Brazilian study conducted by Monteiro et al., for women under 19 years, the finding was of $20 \%$ of intraepithelial lesions, with $3 \%$ of high-grade lesions and one case of invasive cancer. These rates were superior to ours. The authors concluded that the young population should be screened aiming to treat lesions early and avoid the risk of progression to invasive cancer. ${ }^{(4)}$

A study by the Instituto Adolfo Lutz observed a high incidence of high-grade lesions in the age group under 34 years. The fact that $24.3 \%$ of these lesions were found in women aged under 25 years stood out. ${ }^{(17)}$ In our series of cases, the high-grade lesion cytology finding was low, although among the cases selected with ASCUS + cytology, confirmed by histopathology, the values were similar in women under 25 years of age.

In the screening program of SISCOLO, from 2008 to 2011 , with reference to indigenous women, they occupied $0.3 \%$ of the entire population screened; $20 \%$ of the tests in this population were performed in women aged under 25 years. These rates were significantly lower than those presented in our study. ${ }^{(18)}$ The cytological alterations were also lower, with $2.1 \%$ of the tests represented; the finding of low-grade lesions occurred in $0.48 \%$ and of high-grade lesions, in $0.33 \%$. This perhaps happened due to the fact that we are here representing only indigenous women, from an isolated region, with restricted access and devoid of screening tests for cervical cancer until 2005. On the other hand, in the SISCOLO program, the scope was in indigenous individuals of the whole country, mixed in with the white population, many of them living in urban areas where access to healthcare is more widespread, with greater ease for screening. Additionally, the SISCOLO data represent a small portion of the indigenous female population of the country that was submitted to the prevention testing and was followed vertically, 
meaning, there is no posterior information on followup. In PIX, a horizontal program was carried out that allowed prevention, diagnosis, treatment, and follow-up of these women during 6 years. These data are yet unpublished in Brazil, since it is still very difficult to develop and maintain a prevention program in isolated areas, with difficult access, and with a high turnover of professionals. There are no national studies that evaluate the progression of cervical lesions in the indigenous population, which generates lack of confidence in the watchful waiting approach for these women, as well as no screening in age groups not recommended for women of the general population. Partnership with the university was fundamental, since by means of matrix actions with specialized professionals, it was possible to maintain an organized program in a continuous form and adapted to the indigenous reality.

In subdividing the young women into three distinct age groups, we observed a predominance of women under 18 years. The older population, on the other hand, over 65 years, is restricted, probably due to a shorter survival of the indigenous women due to other comorbidities.

In our study, we covered all the sexually active women, since sexual initiation begins very early and there is not yet a well-established program for this population, we chose to screen all women with a history of already having initiated their sexual live, with annual or biannual intervals in screening, with the objective of outlining their profile, and thus establishing what would be best for the indigenous women. With this investigation of five consecutive actions, it was made clear that the lesions are frequent in young women, but with the predominance of low-grade lesions. The cases of high-grade lesions occurred at ages under 25 years.

The three cases of CIN II were found in an extremely young age group. Based on the various articles that believe in spontaneous remission of these lesions in adolescents, varying from 40 to $60 \%$, it is possible to adopt a watchful waiting approach. ${ }^{(19-23)}$ Nevertheless, little is known as to the behavior of these lesions in indigenous women, besides the risk of loss in followup of these women due to difficult access of the teams, the risk of inconsistency of the actions, and constant moving of these women from one village to another, which could impede watchful waiting with regular follow-ups. In these same papers in which a high rate of spontaneous regression is characterized, the rates of persistence and of progression are considerable, taking into account the same 40 to $60 \%$, which would place at risk the special type of study population due to the possibility of not having regular accompaniment. ${ }^{(22,23)}$
On the other hand, the three cases presented with a diagnosis of CIN III were in the age group 22-24 years, demonstrating that the age group recommended by the Ministry of Health for conducting screening using the Papanicolaou method excludes from the system young patients, potentially carriers of high-risk lesions with a progression risk for cancer. These cases, regardless of the age range, have indication for immediate treatment. The outcome of the natural history of HPV infection can be damaging to the health of these young indigenous women, since the orientation officially accepted for the Brazilian female population does not take into consideration the nuances of behavior and the association of risk factors. Therefore, good medical judgment should prevail for special situations. The largest contingent of young women in this study was in the age group of less than 18 years, which, in the majority of cases would not be included for cervical cancer screening. Thus, we conclude that there was excessive coverage, with a waste of investments, since in this population there would be no indication for treatment of intraepithelial lesions. In this age group, using funds for massive vaccination against HPV would be recommended. However, the prevention actions over these consecutive years, even at early ages, provided us with knowledge about the behavior of infection and of the lesions in these women, and thus, the chance to establish a new screening program for this special population.

Nonetheless, the results obtained in elderly women show that the low occurrence of cytological atypia justifies the respect for the upper age limit of 64 years, as is established by the MS/INCA, as long as they have previous negative test results and no history of cervical pathology. The three cases of high-grade lesion presented in this age range had prior cytology alterations, which would indicate no interruption in screening.

If we consider the data obtained in our study and adopt the practice of countries that begin screening at 25 years of age, including Brazil, some of our indigenous young women, despite not in a large number, would have serious cervical lesions for a very long period, until they reached the age suggested for screening. Additionally, the possibility of losing these women, who constantly move from one village to another, and many times change their very names, would lead to discontinuing the follow-up. Therefore, based on institutions such as ACOG and ASCCP, which recommend that the first prevention examination be done at 21 years of age and the treatment of the CIN III lesions in young women, we chose for this type of population, an earlier beginning of screening. ${ }^{(13,14,19,20,21)}$ 
International data show that only 12 to $45 \%$ of the sexually active adolescents underwent the prevention examination. ${ }^{(23)}$ In our study, the coverage of this age bracket was high. For this reason we suggest that screening should be regular in this group of young women, considering the increase in high-grade lesions among patients aged 20 to 34 years, similar to what is done in Italy, France, Germany, and United States, that start at 20-21 years and never before that. ${ }^{(19,20,21,24,25)}$

\section{CONCLUSION}

In the Xingu Indigenous Park, cervical cancer screening should be initiated at an earlier age than what is recommended by the Instituto Nacional de Câncer/ Ministry of Health, considering that this is a special population at risk of no regular follow-up. The age for ending screening proved consistent with that established in Brazil, i.e., at 64 years of age, as long as there were no alterations in previous tests.

\section{REFERENCES}

1. Ferlay J, Bray F, Pisani P, Parkin DM. Globocan 2002 cancer incidence, mortality and prevalence worldwide. IARC Cancer Base No 5, version 2.0. IARC Press. Lyon; 2004.

2. Brasil. Ministério da Saúde. Instituto Nacional de Câncer (INCA). Estimativa 2014: incidência de câncer no Brasil [Internet]. (citado 2014 Jan 14). Disponível: http://www2.inca.gov.br/HYPERLINK "http://www2. inca.gov.br/wps/wcm/connect/0129ba0041fbbc01aa4fee936e134226/ Apresentacao + Estimativa +2014 final + corrigido + tireoide. $p d f ? \mathrm{MOD}=\mathrm{A}$ JPERES\&CACHEID =0129ba0041fbbc01aa4fee936e134226"wHYPERLINK "http://www2.inca.gov.br/wps/wcm/connect/0129ba0041fbbc01aa4fee93 6e134226/Apresentacao + Estimativa + 2014_final + corrigido + tireoide.pd

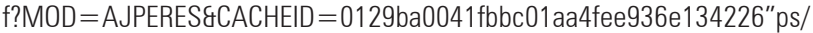
wcm/connect/0129ba0041fbbc01aHYPERLINK

3. Moscicki AB, Ellenberg JH, Vermund SH, Holland CA, Darragh T, CrowleyNowick PA, et al. Prevalence of and risks for cervical human papillomavirus infection and squamous intraepithelial lesions in adolescent girls: impact of infection with human immunodeficiency virus. Arch PediatrAdolesc Med. 2000;154(2):127-34.

4. Monteiro DL, Trajano AJ, Silva KS, Russomano FB. Incidência de lesões intraepiteliais cervicais em população de adolescentes atendidas em serviço público de saúde no Rio de Janeiro, Brasil. Cad Saúde Pública. 2009;25(5):1113-22.

5. Moscicki AB, Shiboski S, Broering J, Powell K, Clayton L, Jay N, et al. The natural history of human papillomavirus infection as measured by repeated DNA testing in adolescent and young women.J Pediatr. 1998;132(2):277-84.

6. Pereira ER. Prevenção do câncer do colo do útero na população feminina do Parque Indígena do Xingu, Mato Grosso [dissertação]. São Paulo: Escola Paulista de Medicina da Unifesp; 2011

7. Insinga RP, Glass AG, Rush BB. Diagnoses and outcomes in cervical cancer screening: A population-based study. Am J Obstet Gynecol. 2004; $191(1): 105-13$.

8. McCredie MR, Sharples KJ, Paul C, Baranyai J, Medley G, Jones RW, et al. Natural history of cervical neoplasia and risk of invasive cancer in women with cervical intraepithelial neoplasia 3: a retrospective cohort study. Lancet Oncol. 2008;9(5):425-34.

9. Solomon D, Davey D, Kurman R, Moriarty A, O'Connor D, Prey M, Raab S, Sherman M, Wilbur D, Wright T Jr, Young N; Forum Group Members; Bethesda 2001 Workshop. The 2001 Bethesda System: terminology for reporting results of cervical cytology. JAMA. 2002;287(16):2114-9. Review.

10. Ostör AG. Natural history of cervical intraepithelial neoplasia: a critical review. Int J Gynecol Pathol. 1993;12(2):186-92. Review.

11. Castle PE, Schiffman M, Wheeler CM, Solomon D. Evidence for frequent regression of cervical intraepithelial neoplasia-grade 2. Obstet Gynecol. 2009;113(1):18-25

12. Instituto Nacional de Câncer (INCA). Coordenação Geral de Ações Estratégicas. Divisão de Apoio à Rede de Atenção Oncológica. Diretrizes brasileiras para 0 rastreamento do câncer do colo do útero. Rio de Janeiro: INCA; 2011. p. 33-34.

13. Committee on Adolescent Health Care. ACOG Committee Opinion No. 436 evaluation and management of abnormal cervical cytology and histology in adolescents. Obstet Gynecol. 2009;113(6):1422-5.

14. Saslow D, Solomon D, Lawson HW, Killackey M, Kulasingam SL, Cain J, Garcia FA, Moriarty AT, Waxman AG, Wilbur DC, Wentzensen N, Downs LS Jr, Spitzer M, Moscicki AB, Franco EL, Stoler MH, Schiffman M, Castle PE, Myers ER; ACSASCCP-ASCP Cervical Cancer Guideline Committee. American Cancer Society, American Society for Colposcopy and Cervical Pathology, and American Society for Clinical Pathology screening guidelines for the prevention and early detection of cervical cancer. CA Cancer J Clin. 2012;62(3):147-72.

15. de Gois Speck NM, Pereira ER, Schaper M, Rodrigues D, Almeida P, Sakano CR, et al. Cytopathological screening in indigenous women from Parquelndígena do Xingu. Eur J Gynaec Oncol. 2009;30(5):512-3.

16. World Health Organization (WHO). Cervical cancer screening in developing countries: report a who consultation. France: World Health Organization (WHO); 2002.

17. Etlinger D, Pereira SM, Oikawa KF, Marin AC, Araújo RS, Souza CJ, et al. Campanha de prevenção de câncer cervical: estudos no Instituto Adolfo Lutz mostram a necessidade de avaliação na faixa etária. Rev Inst Adolfo Lutz. 2008;67(1):64-8.

18. Pla MA, Correa FM, Claro IB, Silva MA, Dias MB, Bortolon PC. Análise descritiva do perfil dos exames citopatológicos do colo do útero realizados em mulheres indígenas e não indígenas no Brasil, 2008-2011. Rev Bras Cancer 2012;58(3):461-469.

19. Linos A, Riza E. Comparisons of cervical cancer screening programmes in the European Union. Eur J Cancer. 2000 Nov;36(17):2260-5.

20. Mayor S. NHS cervical screening programme to introduce liquid based cytology. BMJ. 2003;327(7421):948.

21. Canadian Task Force on Preventive Health Care, Dickinson J, Tsakonas E, Conner Gorber S, Lewin G, Shaw E, Singh H, Joffres M, Birtwhistle R, Tonelli M, Mai V, McLachlin M. Recommendations on screening for cervical cancer. CMAJ. 2013;185(1):35-45

22. McAllum B, Sykes PH, Sadler L, Macnab H, Simcock BJ, Mekhail AK.. Is the treatment of CIN 2 always necessary in women under 25 years old? Am Am J Obstet Gynecol. 2011;205(5):478.e1-7.

23. Vetrano G, Lombardi G, Di Leone G, Parisi A, Scardamaglia P, Pate G, et al Cervical intraepithelial neoplasia: risk factors for persistence and recurrence in adolescents. Eur J Gynaecol Oncol. 2007;28(3):189-92.

24. Coppell K, Paul C, Cox B. An evaluation of the National Cervical Screening Programme Otago site. N Z Med. 2000;113(1104):48-51.

25. Bano F, Kolhe S, Zamblera D, Jolaoso A, Folayan O, Page L, et al. Cervical screening in under 25s: a high-risk Young population. Eur J Obstet Gynecol Reprod Biol. 2008;139(1):86-9. 